\title{
TINGKAT KETAHANAN PANGAN RUMAH TANGGA NELAYAN DI DESA SUKAJAYA LEMPASING KECAMATAN TELUK PANDAN KABUPATEN PESAWARAN
}

\author{
(Food Security Level of Fisherman Household in Sukajaya Lempasing Village, \\ Teluk Pandan Subdistrict of Pesawaran Regency)
}

Defline Putri Delly, Fembriarti Erry Prasmatiwi, Rio Tedi Prayitno

\begin{abstract}
Jurusan Agribisnis, Fakultas Pertanian, Universitas Lampung, Jl. Prof. Dr. Soemantri Brodjonegoro No. 1 Bandar Lampung 35141, Telp. 081244456068,e-mail: deflineputri@gmail.com
\end{abstract}

\begin{abstract}
The aim of this research are to analyze the level of food security, the factors that affect the level of food security, and efforts to increase the level of food security of fisherman household. The location of this research is chosen purposively in Sukajaya Lempasing Village, Teluk Pandan Subdistrict, Pesawaran Regency in which respondents are 51 fisherman households. The data of this research was primary data and secondary data, collected in February - May 2018 and analyzed by cross-classification between the share of food expenditure and energy adequacy level, ordinal logistic regression, and descriptive qualitative analysis. The results of the research showed that the majority of respondent (68.63\%) were classified as less food, and the rest were classified as food secure (13.73\%), vulnerable to food (5.88\%), and food insecure (11.76\%). The affecting factors on the level of food security were formal education level of housewives and household food expenditure. The efforts to increase the level of food security by Government were through monitoring food availability and food reserves, developing food distribution and stabilization of food prices, Program Keluarga Harapan (PKH), and Raskin. Whereas, the efforts by fisherman household themselves were food loan (92.16\%) and changing dietary habit (7.84\%).
\end{abstract}

Key words: cross-classification, fisherman household, food security

\section{PENDAHULUAN}

Provinsi Lampung memiliki wilayah pesisir yang luas dan potensi sumber daya perikanan laut. Kabupaten Pesawaran memiliki jumlah rumah tangga perikanan laut tertinggi sebesar 1.871 rumah tangga atau 25,14 persen dari keseluruhan rumah tangga perikanan laut di Provinsi Lampung, akan tetapi produktivitasnya relatif lebih rendah dibandingkan dengan kabupaten lain (Badan Pusat Statistik 2016). Pada tahun 2015, hasil produksi perikanan tangkap Kabupaten Pesawaran hanya menempati posisi ke-enam di Provinsi Lampung dengan hasil produksi sebesar 13.956,26 ton. Kecamatan Teluk Pandan memiliki hasil produksi perikanan tangkap dari perairan laut tertinggi di Kabupaten Pesawaran yaitu sebesar 4.597,89 ton dan mengalami peningkatan yang cukup signifikan dengan jumlah peningkatan sebesar 2.574,14 ton dari tahun sebelumnya (Dinas Kelautan dan Perikanan Kabupaten Pesawaran 2016).

Desa Sukajaya Lempasing merupakan salah satu desa di wilayah pesisir Kecamatan Teluk Pandan dengan mayoritas masyarakatnya berprofesi sebagai nelayan. Aktivitas ekonomi masyarakat pesisir berpengaruh dalam meningkatkan pertumbuhan ekonomi, akan tetapi pertumbuhan ekonomi tersebut belum dapat dirasakan oleh seluruh masyarakat. Nelayan sebagai masyarakat pesisir dominan memiliki tingkat kesejahteraan yang rendah karena menghadapi masalah kemiskinan. Permasalahan yang terjadi dalam usaha ikan tangkap nelayan adalah persaingan antara nelayan yang semakin meningkat, keterbatasan daerah penangkapan, dan sulit memperoleh bantuan modal, sehingga menghambat operasi penangkapan ikan (Pemerintah Daerah Provinsi Lampung 1999).

Kemiskinan dan tekanan ekonomi merupakan masalah yang dihadapi oleh rumah tangga nelayan. Menurut Badan Ketahanan Pangan Kementerian Pertanian (2016), kemiskinan berhubungan erat dengan kerawanan pangan, meskipun tidak identik. Indikator tingkat ketahanan pangan ditunjukkan dengan kecukupan konsumsi kalori per kapita per hari dengan nilai AKG $2.150 \mathrm{kkal} / \mathrm{kapita} / \mathrm{hari}$ (Widyakarya Nasional Pangan dan Gizi 2012). Berdasarkan hasil survei konsumsi pangan, tingkat konsumsi rumah tangga di Kabupaten Pesawaran hanya sebesar 1.919,7 kkal/kapita/hari, konsumsi 
energi tersebut masih di bawah standar yang ditetapkan (Dinas Ketahanan Pangan Kabupaten Pesawaran 2017)

Undang-Undang Republik Indonesia Nomor 18 Tahun 2012 mendefinisikan ketahanan pangan sebagai kondisi terpenuhinya pangan bagi negara sampai dengan perseorangan, yang tercermin dari tersedianya pangan yang cukup, baik jumlah maupun mutunya, aman, beragam, bergizi, merata, dan terjangkau serta tidak bertentangan dengan agama, keyakinan, dan budaya masyarakat, untuk dapat hidup sehat, aktif, dan produktif secara berkelanjutan. Merujuk dalam Kebijakan Strategis Pangan dan Gizi 2015 - 2019 (Dewan Ketahanan Pangan 2015), Committee on World Food Security dan Food and Agriculture Organization (CFS$F A O)$ menyatakan ada empat pilar ketahanan pangan yaitu ketersediaan (availability), keterjangkauan (access), pemanfaatan (utilization), dan kestabilan (stability). Jika pangan tersedia cukup di tingkat nasional dan regional, tetapi tidak diiringi dengan akses individu untuk memenuhi kebutuhan pangan tidak merata, maka ketahanan pangan masih dikatakan rapuh (Adriani dan Wirjatmadi 2010).

Menurut Salim dan Darmawanty (2016), kondisi ketahanan pangan bagi rumah tangga nelayan sulit dicapai apabila akses rumah tangga nelayan terhadap pangan dalam kondisi yang rendah, khususnya dari sisi ekonomi seperti pendapatan, kesempatan kerja dan harga pangan. Tidak hanya akses pangan yang lemah, rumah tangga nelayan juga sangat mungkin mengalami ketidakpastian dalam mencapai kondisi kecukupan pangan, jaminan pangan, serta keberlanjutan pangan. Penelitian ini bertujuan untuk menganalisis tingkat ketahanan pangan, faktor-faktor yang mempengaruhi tingkat ketahanan pangan, dan upaya yang dilakukan oleh pemerintah dan rumah tangga nelayan untuk meningkatkan tingkat ketahanan pangan rumah tangga nelayan.

\section{METODE PENELITIAN}

Penelitian ini dilaksanakan dengan menggunakan metode survei di Desa Sukajaya Lempasing Kecamatan Teluk Pandan Kabupaten Pesawaran yang dipilih secara sengaja (purposive) dengan pertimbangan Kabupaten Pesawaran memiliki jumlah rumah tangga nelayan tertinggi di Provinsi Lampung, Kecamatan Teluk Pandan memiliki hasil produksi perikanan laut tangkap tertinggi di Kabupaten Pesawaran, dan masyarakat Desa Sukajaya lempasing sebagian besar berprofesi sebagai nelayan. Pengambilan data dan pengolahan data dilakukan pada bulan Februari sampai dengan Mei 2018.

Jenis data yang digunakan terdiri dari data primer dan sekunder. Data primer diperoleh melalui wawancara langsung dengan responden dipandu kuesioner. Data sekunder diperoleh dari instansi dan literature terkait. Populasi dalam penelitian ini adalah 335 rumah tangga nelayan dengan pengambilan sampel menggunakan metode simple random sampling. Penentuan jumlah responden mengacu pada rumus Arikunto (2010), dimana sampel diambil sebanyak 10 persen dari populasi (51 rumah tangga nelayan).

Tujuan penelitian pertama adalah menganalisis tingkat ketahanan pangan rumah tangga nelayan yang diukur dengan menggunakan indikator klasifikasi silang antara pangsa pengeluaran pangan dan kecukupan energi yang dikembangkan oleh Johnson dan Toole dalam Maxwell, et al (2000) yang dapat dilihat dalam Tabel 1. Data konsumsi riil pangan rumah tangga dihitung dengan rumus sebagai berikut (Perdana dan Hardinsyah 2013):

$\mathrm{Gj}=\left(\frac{B P \mathrm{j}}{100} \times \frac{\text { Bddj }}{100}\right) \times \mathrm{KG} j$

Keterangan:

Gj(A) : Jumlah energi atau protein yang dikonsumsi dari pangan $\mathrm{j}$ (energi dalam satuan kilokalori (kkal) dan protein dalam satuan gram)

$\mathrm{BPj} \quad$ : Berat dari pangan $\mathrm{j}$ yang dikonsumsi (gram)

KGij : Kandungan energi atau protein per 100 gram pangan $\mathrm{j}$ yang dikonsumsi (energi dalam satuan kkal dan protein dalam satuan gram)

Bddj : Bagian yang dapat dimakan dari 100 gram pangan $\mathrm{j}(\%)$

Tabel 1. Kriteria tingkat ketahanan pangan rumah tangga

\begin{tabular}{lcc}
\hline \multirow{2}{*}{ Konsumsi energi } & \multicolumn{2}{c}{ Pangsa pengeluaran pangan } \\
\cline { 2 - 3 } & $\begin{array}{l}\text { Rendah } \\
(<60 \%)\end{array}$ & $\begin{array}{c}\text { Tinggi } \\
(\geq 60 \%)\end{array}$ \\
\hline Cukup $(>80 \%)$ & Tahan pangan & Rentan pangan \\
Kurang $(\leq 80 \%)$ & $\begin{array}{l}\text { Kurang } \\
\text { pangan }\end{array}$ & Rawan pangan \\
\hline \multicolumn{2}{l}{ Sumber: Johnsson and Toole 1991 dalam Maxwell 2000 }
\end{tabular}


Angka Kecukupan Energi (AKE) dihitung dengan rumus sebagai berikut (Hardinsyah dan Martianto 1989):

AKE-i $=\left(\frac{\text { BB aktual }(\mathrm{kg})}{\mathrm{BB} \text { standar }(\mathrm{kg})}\right) \times$ AKE standar

Keterangan:

$\begin{array}{ll}\text { AKE-i } & \text { : Angka kecukupan energi } \\ \text { BB aktual } & \text { : Berat badan aktual } \\ \text { BB standar } & : \text { Berat badan standar } \\ \text { AKE standar } & \text { AKE anjuran WNPG } 2012 \\ \text { AKE-RT } & : \text { EAKE-i }\end{array}$

Dalam Perdana dan Hardinsyah (2013), tingkat kecukupan energi (TKE) dirumuskan sebagai berikut:

$\mathrm{TKE}=\frac{\sum \text { Konsumsi Energi (A) }}{\text { AKE-RT yang dianjurkan }} \times 100 \%$

Pangsa pengeluaran pangan dihitung dengan rumus sebagai berikut:

$\mathrm{PPP}=\mathrm{PP} / \mathrm{T} \times 100 \%$

Keterangan:

PPP : Pangsa pengeluaran pangan (\%)

PP : Pengeluaran untuk belanja pangan (Rp/bulan)

$\mathrm{T}$ : Total pengeluaran rumah tangga (Rp/bulan)

Tujuan penelitian ke-dua yaitu analIsis faktorfaktor yang mempengaruhi tingkat ketahanan pangan dianalisis dengan regresi ordinal logit dengan persamaan sebagai berikut.

$$
\begin{aligned}
\mathrm{Zi}= & \operatorname{Ln}\left[\frac{\mathrm{Pi}}{1-\mathrm{Pi}}\right]=\alpha+\beta_{1} \mathrm{X}_{1}+\beta_{2} \mathrm{X}_{2}+\beta_{3} \mathrm{X}_{3}+\beta_{4} \mathrm{X}_{4}+ \\
& \beta_{5} \mathrm{X}_{5+} \beta_{6} \mathrm{X}_{6+} \beta_{7} \mathrm{X}_{7+} \beta_{8} \mathrm{X}_{8} \mathrm{e} \ldots \ldots \ldots \ldots \ldots \ldots \ldots . . . . . . . . . . . . . .
\end{aligned}
$$

Keterangan:

$\mathrm{Zi} \quad$ : Peluang $\mathrm{Z1}=\mathrm{Z}(\mathrm{Y}=4)$ untuk rumah tangga nelayan tahan pangan, Peluang $\mathrm{Z} 2=\mathrm{Z}(\mathrm{Y}=3)$ untuk rumah tangga nelayan kurang pangan, Peluang $\mathrm{Z3}=$ $\mathrm{Z}(\mathrm{Y}=2)$ untuk rumah tangga nelayan rentan pangan, Peluang $\mathrm{Z} 4=\mathrm{Z}(\mathrm{Y}=1)$ untuk rumah tangga nelayan rawan pangan

$\mathrm{Pi} \quad$ : Peluang nelayan untuk menentukan tingkat ketahanan pangan bila $\mathrm{Xi}$ diketahui

$\alpha \quad$ : Intersep

$\beta_{1}-\beta_{8}:$ Koefisien variabel bebas
$\mathrm{X}_{1} \quad$ : Jumlah anggota keluarga (orang)

$\mathrm{X}_{2}$ : Tingkat pendidikan ibu rumah tangga (tahun sukses)

$\mathrm{X}_{3} \quad: \quad$ Harga beras $(\mathrm{Rp} / \mathrm{kg})$

$\mathrm{X}_{4} \quad$ : Harga minyak goreng $(\mathrm{Rp} / \mathrm{liter})$

$\mathrm{X}_{5} \quad$ : Harga tepung terigu $(\mathrm{Rp} / \mathrm{kg})$

$\mathrm{X}_{6} \quad$ : Harga gula $(\mathrm{Rp} / \mathrm{kg})$

$\mathrm{X}_{7}$ : Pendapatan rumah tangga (Rp/bulan)

$\mathrm{X}_{8} \quad$ : Pengeluaran pangan rumah tangga (Rp/bulan)

e : Error term

Estimasi model logit menggunakan uji Likelihood Ratio (LR) untuk mengetahui tingkat pengaruh seluruh variabel independen secara bersama-sama terhadap variabel dependen, Nilai LR sama dengan Pseudo $\mathrm{R}^{2}$. Uji Wald dilakukan untuk menguji pengaruh secara individu variabel independen terhadap variabel dependen. Uji Goodness of Fit untuk mengetahui seberapa baik model dalam menjelaskan hubungan antara variabel dependen dengan variabel independennya.

Tujuan penelitian ke-tiga yaitu analisis upaya meningkatkan ketahanan pangan dianalisis secara deskriptif untuk mengetahui upaya yang dilakukan oleh pemerintah dan rumah tangga nelayan untuk meningkatkan tingkat ketahanan pangan.

\section{HASIL DAN PEMBAHASAN}

\section{Karakteristik Responden}

Mayoritas usia kepala keluarga berkisar antara 50 - 60 tahun dan ibu rumah tangga berkisar antara 38 - 49 tahun, serta tidak ada yang berusia kurang dari 15 tahun dan lebih dari 65 tahun. Hal ini menunjukkan bahwa usia seluruh kepala keluarga dan ibu rumah tangga termasuk dalam usia produktif (Mantra 2004). Mayoritas kepala keluarga dan ibu rumah tangga hanya menempuh pendidikan sampai tingkat Sekolah Dasar (SD).

Rata-rata jumlah anggota rumah tangga nelayan sebanyak 5 orang yang berarti bahwa jumlah anggota rumah tangga melebihi standar Norma Keluarga Kecil Bahagia dan Sejahtera (NKKBS) yaitu sebanyak $\leq 4$ orang/rumah tangga. Seluruh kepala keluarga berprofesi sebagai nelayan, hanya 1,96 persen diantaranya melakukan pekerjaan tambahan di luar usaha ikan tangkap dengan bekerja sebagai pengrajin ikan asin, 1,96 persen sebagai pengrajin ikan fillet, dan sebesar 7,84 persen ibu rumah tangga bekerja sebagai pengrajin ikan fillet. 
Tabel 2. Rata-rata total pendapatan rumah tangga nelayan di Desa Sukajaya Lempasing

\begin{tabular}{lcr}
\hline \multicolumn{1}{c}{ Sumber Pendapatan } & $\begin{array}{c}\text { Pendapatan RT } \\
\text { (Rp/tahun) }\end{array}$ & \multicolumn{1}{c}{$\begin{array}{c}\text { Proprosi } \\
(\%)\end{array}$} \\
\hline - Usaha ikan tangkap & $40.719 .746,70$ & 84,78 \\
- Di luar usaha ikan & & \\
tangkap & $3.035 .294,12$ & 6,32 \\
- Non perikanan & $3.682 .352,94$ & 7,52 \\
- Bantuan pemerintah & $588.235,29$ & 1,38 \\
\hline Jumlah & $48,025,629.08$ & 100,00 \\
\hline
\end{tabular}

Pada Tabel 2 dapat dilihat bahwa sebagian besar pendapatan rumah tangga nelayan di Desa Sukajaya Lempasing diperoleh dari usaha ikan tangkap yaitu sebesar Rp40.719.746,70 dalam satu tahun. Rata-rata total pendapatan rumah tangga nelayan dalam satu bulan sebesar Rp4.002.138,77 atau sebesar Rp813.442,84/kapita/bulan yang mengindikasikan pendapatan per kapita rumah tangga nelayan berada di atas standar garis kemiskinan masyarakat pedesaan yang ditetapkan oleh BPS Provinsi Lampung pada tahun 2014 2017 yaitu sebesar Rp377.049,00/kapita/bulan (BPS Provinsi Lampung 2018).

\section{Ketahanan Pangan Rumah Tangga}

\section{Ketersediaan pangan}

Pengeluaran rumah tangga terdiri dari pengeluaran pangan dan pengeluaran non pangan. Pada Tabel 3 dapat dilihat pengeluaran pangan rumah tangga nelayan terbesar dibelanjakan untuk pangan pokok sebesar Rp535.598,04 (33,14\%) dari total pengeluaran pangan dan lauk-pauk sebesar Rp505.656,70 (31,29\%) dari total pengeluaran pangan yang diperoleh dari membeli, kecuali ikan laut yang diperoleh dari hasil produksi.

Tabel 3. Rata-rata total pengeluaran pangan rumah tangga nelayan di Desa Sukajaya Lempasing

\begin{tabular}{lrc}
\hline \multicolumn{1}{c}{ Jenis Pengeluaran } & \multicolumn{1}{c}{ Jumlah $(\mathrm{Rp})$} & Proporsi $(\%)$ \\
\hline - Pangan Pokok & $535.598,04$ & 33,14 \\
- Lauk-Pauk & $505.656,70$ & 31,29 \\
- Kacang-Kacangan & $9.374,18$ & 0,58 \\
- Sayuran & $166.081,70$ & 10,28 \\
- Buah-buahan & $35.411,76$ & 2,19 \\
- Lemak & $31.588,24$ & 1,95 \\
- Makanan Jajanan & $41.062,75$ & 2,54 \\
- Minuman & $120.542,33$ & 7,46 \\
- Bumbu & $170.805,88$ & 10,57 \\
\hline Jumlah & $1.616 .121,58$ & 100,00 \\
\hline
\end{tabular}

Tabel 4. Rata-rata total pengeluaran rumah tangga nelayan di Desa Sukajaya Lempasing dalam satu bulan

\begin{tabular}{lrr}
\hline \multicolumn{1}{c}{ Keterangan } & \multicolumn{1}{c}{ Jumlah (Rp) } & Proporsi (\%) \\
\hline Pangan & $1.616 .121,58$ & 50,13 \\
Non Pangan & & \\
- Listrik & $64.627,45$ & 2,00 \\
- Gas & $51.764,71$ & 1,61 \\
- Bahan bakar & $2.6125,49$ & 0,81 \\
- Rokok & $494.862,75$ & 15,35 \\
- SPP & $7.6045,75$ & 2,36 \\
- Uang saku & $597.803,92$ & 18,54 \\
- Pakaian & $103.349,67$ & 3,21 \\
- Kesehatan & $15.000,00$ & 0,47 \\
- Arisan & $1.960,78$ & 0,06 \\
- Komunikasi & $46.882,35$ & 1,45 \\
- Sabun & $105.990,20$ & 3,29 \\
- Kecantikan & 7467,32 & 0,23 \\
- Sumbangan & 2941,18 & 0,09 \\
- Mengirim saudara & $12.745,10$ & 0,40 \\
Total pengeluaran non & & \\
pangan & $1.607 .566,67$ & 49,87 \\
\hline Jumlah & $3.223 .688,24$ & 100,00 \\
\hline
\end{tabular}

Rata-rata kebutuhan pangan pokok berupa beras dalam tiap rumah tangga dalam satu bulan sebanyak $43,15 \mathrm{~kg}$. Kebutuhan beras tersebut diperoleh dari membeli sebanyak 41,67 kg/bulan dan bantuan pemerintah melalui program raskin sebanyak $1,48 \mathrm{~kg} / \mathrm{bulan}$. Sebagian kecil rumah tangga (1,97\%) mempunyai cadangan pangan berupa beras dengan rata-rata cadangan pangan seluruh rumah tangga sebesar $1,47 \mathrm{~kg} / \mathrm{bulan} /$ rumah tangga.

Pengeluaran non pangan akan mempengaruhi total pengeluaran rumah tangga. Pengeluaran non pangan terbesar adalah pengeluaran untuk uang saku anak sekolah sebesar Rp597.803,92 (18,54\%) dari total pengeluran rumah tangga dan rokok sebesar Rp494.862,75 (15,35\%) dari total pengeluaran rumah tangga. Hal ini menunjukkan bahwa rumah tangga belum mampu mengalokasikan pengeluarannya dengan baik untuk mencukupi kebutuhan energi rumah tangga. Rumah tangga sebaiknya mengalokasikan pengeluaran rokok untuk mencukupi kebutuhan pangannya.

Pada Tabel 4, dapat dilihat rata-rata pengeluaran pangan rumah tangga nelayan dalam satu bulan adalah sebesar Rp1.616.121,58 (50,13\%) dari total pengeluaran rumah tangga, sedangkan rata-rata pengeluaran non pangan rumah tangga adalah sebesar Rp1.607.566,67 (49,87\%) dari total pengeluaran rumah tangga. Hal ini menunjukkan bahwa pengeluaran pangan mendominasi pengeluaran total rumah tangga. 
Tabel 5. Pangsa pengeluaran pangan rumah tangga nelayan di Desa Sukajaya Lempasing

\begin{tabular}{cccc}
\hline $\begin{array}{c}\text { Pangsa } \\
\text { Pengeluaran } \\
\text { Pangan }\end{array}$ & Kategori & $\begin{array}{c}\text { Jumlah } \\
(\mathrm{n})\end{array}$ & $\begin{array}{c}\text { Proporsi } \\
(\%)\end{array}$ \\
\hline$<60 \%$ & Rendah & 42 & 82,35 \\
$\geq 60 \%$ & Tinggi & 9 & 17,65 \\
\hline Jumlah & & 51 & 100,00 \\
\hline
\end{tabular}

Ketersediaan pangan dicerminkan dari pangsa pengeluaran pangan rumah tangga yang terdiri dari dua kategori, yaitu tinggi dan rendah. Pangsa pengeluaran tinggi menggambarkan ketersediaan pangan yang yang belum cukup, sedangkan pangsa pengeluaran rendah menggambarkan ketersediaan pangan yang cukup (Purwaningsih 2008). Hasil penelitian pada Tabel 5 menunjukkan sebanyak 82,35 persen rumah tangga nelayan memiliki pangsa pengeluaran yang rendah. Pangsa pengeluaran yang rendah mengindikasikan pendapatan rumah tangga cukup tinggi, sedangkan pangsa pengeluaran yang tinggi mengindikasikan pendapatan rumah tangga rendah. Rumah tangga berpendapatan tinggi berarti memiliki daya beli yang lebih tinggi untuk memenuhi kebutuhan pangan daripada rumah tangga berpendapatan rendah

\section{Distribusi (akses) pangan}

Akses pangan secara fisik ditunjukkan dengan kemampuan memproduksi pangan, kondisi infrastruktur dan sumber daya alam dan lingkungan pada wilayah tersebut. Seluruh rumah tangga nelayan tidak memiliki akses langsung terhadap bahan pangan pokok karena tidak memproduksi beras, akan tetapi memiliki akses langsung terhadap bahan pangan hewani berupa ikan segar karena melakukan kegiatan usaha ikan tangkap, sedangkan bahan pangan lainnya, diperoleh dengan cara membeli atau merupakan bahan pangan pemberian. Secara ekonomi, akses pangan dicerminkan dengan keterjangkauan harga pangan di wilayah tersebut, berdasarkan hasil pengamatan, bahan pangan selalu tersedia di pasar, toko, serta warung yang ada di lokasi penelitian dengan harga terjangkau.

\section{Konsumsi pangan}

Tingkat kecukupan energi rumah tangga diperoleh dari penghitungan konsumsi energi riil rumah tangga dibagi dengan angka kecukupan energi yang dianjurkan berdasarkan jenis kelamin, usia, dan berat badan seluruh anggota dalam satu rumah tangga.
Tabel 6. Sebaran Tingkat kecukupan energi dan protein rumah tangga nelayan di Desa Sukajaya Lempasing

\begin{tabular}{llrr}
\hline \multicolumn{1}{c}{ Indikator } & Kategori & Jumlah (n) & Proporsi (\%) \\
\hline Energi & & & \\
\hline$>80 \%$ & Cukup & 10 & 19,61 \\
$\leq 80 \%$ & Kurang & 41 & 80,39 \\
\hline Jumlah & & 51 & 100,00 \\
\hline Protein & & & \\
\hline$\geq 80 \%$ & Cukup & 27 & 52,94 \\
$<80 \%$ & Kurang & 24 & 47,06 \\
\hline Jumlah & & 51 & 100,00 \\
\hline
\end{tabular}

Rata-rata konsumsi energi rumah tangga nelayan adalah sebesar 7.911,32 kkal/rumah tangga dengan tingkat kecukupan energi rumah tangga sebesar 75,20 persen. Pada Tabel 6 dapat dilihat bahwa mayoritas rumah tangga nelayan (80,39\%) memiliki tingkat kecukupan energi yang tergolong dalam kategori rendah. Rata-rata konsumsi energi per kapita hanya sebesar 1607,99 kkal, konsumsi tersebut jauh di bawah standar angka kecukupan energi yang dianjurkan dalam Widyakarya Nasional Pangan dan Gizi (WNPG) X Tahun 2012.

Rata-rata konsumsi protein rumah tangga nelayan adalah sebesar 215,52 gr/rumah tangga dengan tingkat kecukupan protein sebesar 80,89 persen. Pada Tabel 6 dapat dilihat bahwa sebagian besar rumah tangga nelayan $(52,94 \%)$ memiliki tingkat kecukupan protein yang tergolong dalam kategori cukup. Hal ini menunjukkan kebutuhan protein mayoritas rumah tangga nelayan telah terpenuhi, akan tetapi rata-rata konsumsi protein per kapita hanya sebesar 43,80 gr yang berarti konsumsi protein per kapita di bawah angka kecukupan protein yang dianjurkan dalam Widyakarya Nasional Pangan dan Gizi (WNPG) X Tahun 2012.

\section{Analisis Tingkat ketahanan pangan}

Berdasarkan hasil analisis tingkat ketahanan pangan rumah tangga nelayan menggunakan indikator klasifikasi silang yang dikembangkan Jonsson dan Toole dan diadopsi oleh Maxwell, et al (2000), antara pangsa pengeluaran pangan yang dapat dilihat pada Tabel 5 dan kecukupan energi yang dapat dilihat pada Tabel 6. Hasil analisis menunjukkan sebagian besar rumah tangga nelayan $(68,63 \%)$ tergolong dalam kategori kurang pangan, kategori rentan pangan $(3,88 \%)$, kategori rawan pangan $(11,76)$, dan hanya sebagian kecil rumah tangga nelayan yang telah mencapai kondisi tahan pangan $(13,75 \%)$. Sebaran tingkat ketahanan pangan berdasarkan hasil klasifikasi silang dapat dilihat pada Tabel 7 . 
Tabel 7. Sebaran tingkat ketahanan pangan rumah tangga nelayan di Desa Sukajaya Lempasing

\begin{tabular}{lrr}
\hline Tingkat Ketahanan Pangan & Jumlah (n) & Proporsi (\%) \\
\hline Tahan pangan & 7 & 13,75 \\
Kurang pangan & 35 & 68,63 \\
Rentan pangan & 3 & 3,88 \\
Rawan pangan & 6 & 11,76 \\
\hline Jumlah sampel (N) & 51 & 100,00 \\
\hline
\end{tabular}

Tabel 8. Rataan PPP dan TKE rumah tangga nelayan di Desa Sukajaya Lempasing berdasarkan tingkat ketahanan pangan

\begin{tabular}{lrr}
\hline Tingkat Ketahanan Pangan & PPP $(\%)$ & TKE $(\%)$ \\
\hline Tahan pangan & 47,82 & 88,08 \\
Kurang pangan & 47,43 & 72,13 \\
Rentan pangan & 62,31 & 89,10 \\
Rawan pangan & 61,40 & 74,29 \\
\hline
\end{tabular}

Sebagian besar atau 68,63 persen rumah tangga nelayan tergolong dalam kategori kurang pangan dengan rata-rata TKE pada Tabel 8 sebesar 72,13 persen dan PPP sebesar 47,43 persen. Hal ini menunjukkan bahwa kebutuhan energi rumah tangga belum tercukupi, tetapi sebenarnya memiliki daya beli dan akses yang tinggi terhadap pangan karena pangsa pengeluaran pangan rendah yang mengindikasikan bahwa rumah tangga memiliki pendapatan yang tinggi.

Mengacu pada hasil penelitian Anggraini, Zakaria dan Prasmatiwi (2014), rumah tangga kurang pangan disebabkan rumah tangga tersebut kurang dapat mengalokasikan pendapatannya untuk belanja pangan dengan baik, sehingga pangan yang tersedia dan dikonsumsi masih belum dapat memenuhi anjuran angka kecukupan energi. Berdasarkan hal tersebut maka rumah tangga kurang pangan perlu meningkatkan pengetahuan pangan dan gizi agar dapat memilih jenis dan jumlah pangan, sehingga dapat merealokasi pengeluaran pangannya untuk memenuhi kecukupan energi dan zat gizi lainnya sesuai kebutuhan agar mencapai kondisi tahan pangan.

Rumah tangga nelayan yang tergolong dalam kategori tahan pangan hanya sebesar 13,75 persen dengan rata-rata TKE sebesar 88,08 persen dan PPP sebesar 47,82 persen. Hal ini menunjukkan bahwa tingkat konsumsi energi rumah tangga cukup dan memiliki pangsa pengeluaran pangan yang rendah, sehingga mengindikasikan bahwa pendapatan rumah tangga relatif tinggi, dengan diasumsikan harga pangan stabil dan tingkat konsumsi tetap. Keadaan tersebut menunjukkan bahwa rumah tangga telah mengalokasikan pendapatannya dengan baik untuk mencukupi kebutuhan pangan rumah tangganya.

Sebesar 11,76 persen rumah tangga nelayan tergolong dalam kategori rawan pangan dengan rata-rata TKE sebesar 74,29 persen dan PPP sebesar 61,40 persen. Hal ini menunjukkan bahwa rumah tangga rawan pangan memiliki pangsa pengeluaran tinggi, dan kebutuhan energi hariannya belum tercukupi. Rawan pangan terjadi karena pendapatan rumah tangga yang relatif rendah, sehingga tidak mampu mengakses pangan sesuai kebutuhan yang mengakibatkan kebutuhan konsumsi energi tidak dapat tercukupi.

Sebagian kecil atau 5,88 persen rumah tangga nelayan tergolong dalam kategori rentan pangan dengan rata-rata TKE sebesar 89,10 persen dan PPP sebesar 62,31 persen. Hal ini menunjukkan bahwa rumah tangga rentan pangan telah berhasil mencukupi kebutuhan energi hariannya, akan tetapi memiliki pangsa pengeluaran pangan tinggi yang mengindikasikan bahwa rumah tangga tersebut memiliki pendapatan yang relatif rendah, sehingga sebagian besar pendapatannya dikeluarkan untuk belanja pangan. Pendapatan yang rendah mengakibatkan daya beli dan akses rumah tangga terhadap pangan rendah, sehingga meskipun ketersediaan pangan muncukupi, rumah tangga nelayan rentan mengalami rawan pangan, jika pendapatan yang diterima berkurang.

5. Analisis faktor-faktor yang mempengaruhi ketahanan pangan rumah tangga nelayan

Variabel terikat (dependent) yang digunakan berupa data kualitatif yang terdiri dari empat tingkatan kategori ketahanan pangan, yaitu tahan pangan, kurang pangan, rentan pangan, dan rawan pangan. Variabel bebas (Independent) terdiri dari jumlah anggota rumah tangga (X1), tingkat pendidikan ibu rumah tangga (X2), harga beras (X3), harga minyak goreng (X4), harga tepung terigu (X5), harga gula (X6), pendapatan rumah tangga (X7), dan pengeluaran rumah tangga (X8). Berdasarkan hasil regresi ordinal logit terhadap variabel-variabel tersebut, faktor yang berpengaruh positif terhadap tingkat ketahanan pangan rumah tangga nelayan adalah tingkat pendidikan ibu rumah tangga (X2) dan faktor yang berpengaruh negatif terhadap tingkat ketahanan pangan rumah tangga nelayan adalah pengeluaran pangan rumah tangga (X8). Hasil regresi ordinal logit secara lengkap dapat dilihat pada Tabel 9. 
Tabel 9. Hasil regresi ordinal logit faktor-faktor yang mempengaruhi ketahanan pangan

\begin{tabular}{|c|c|c|c|c|}
\hline Variabel & Coef. & $\begin{array}{l}\text { Std. } \\
\text { Error }\end{array}$ & Z-Stat & Prob \\
\hline $\begin{array}{l}\text { - Jumlah anggota } \\
\text { rumah tangga }\end{array}$ & 0,613 & 0,491 & 1,247 & 0,212 \\
\hline $\begin{array}{l}\text { - Tingkat } \\
\text { pendidikan ibu }\end{array}$ & & & & \\
\hline rumah tangga & 0,456 & 0,176 & 2,596 & $0,009 *$ \\
\hline - Harga beras & $-0,000$ & 0,000 & $-0,035$ & 0,972 \\
\hline $\begin{array}{l}\text { - Harga minyak } \\
\text { goring }\end{array}$ & 0,000 & 0,000 & 1,123 & 0,261 \\
\hline $\begin{array}{l}\text { - Harga tepung } \\
\text { terigu }\end{array}$ & $-0,000$ & 0,000 & $-0,972$ & 0,331 \\
\hline - Harga gula & 0,000 & 0,001 & 0,362 & 0,717 \\
\hline $\begin{array}{l}\text { - Pendapatan } \\
\text { rumah tangga }\end{array}$ & 0,000 & 0,000 & 0,331 & 0,740 \\
\hline $\begin{array}{l}\text { - Pengeluaran } \\
\text { pangan rumah } \\
\text { tangga }\end{array}$ & $-0,000$ & 0,000 & $-2,586$ & $0,009 *$ \\
\hline LIMIT_2:C(9) & $-1,453$ & 9,457 & $-0,154$ & $-0,1536$ \\
\hline LIMIT_3:C(10) & $-0,441$ & 9,396 & $-0,047$ & $-0,047$ \\
\hline LIMIT_4:C(11) & 5,230 & 9,427 & 0,554 & 0,555 \\
\hline Pseudo R-squarec & & & & 0,346 \\
\hline LR statistic & & & & 33,470 \\
\hline Prob (LR statistic) & & & & 0,000 \\
\hline
\end{tabular}

Keterangan:

*: Berpengaruh nyata pada taraf kepercayaan 99 persen

Pada Tabel 9 dapat dilihat nilai Pseudo $\mathrm{R}^{2}$ sebesar 0,346 , nilai tersebut menjelaskan bahw sebesar 34,6 persen variasi tingkat ketahanan pangan rumah tangga dapat dijelaskan oleh variasi variabel independen $\mathrm{X}_{1}$ sampai dengan $\mathrm{X}_{8}$. Nilai probability LR statistik sebesar 0,000 menjelaskan bahwa variabel jumlah anggota rumah tangga, tingkat pendidikan ibu rumah tangga, harga beras, harga minyak goreng, harga tepung terigu, harga gula, pendapatan rumah tangga, dan pengeluaran pangan rumah tangga secara bersama-sama berpengaruh nyata terhadap tingkat ketahanan pangan rumah tangga nelayan.

Tingkat pendidikan ibu rumah tangga berpengaruh positif terhadap tingkat ketahanan pangan rumah tangga nelayan dengan tingkat kepercayaan sebesar 99,06 persen. Nurdiani dan Widjojoko (2016) menyatakan bahwa tingkat pendidikan ibu rumah tangga berkaitan dengan kemampuan dan pola pikir dalam mengambil keputusan, khususnya yang berhubungan dengan ketahanan pangan. Semakin tinggi tingkat pendidikan ibu rumah tangga maka semakin rasional dalam mengambil keputusan mengenai pola konsumsi rumah tangganya untuk mempertahankan ketahanan pangan rumah tangganya. Hasil peneltian ini sejalan dengan hasil penelitian Yuliana, Zakaria, dan Adawiyah (2013) yang menyatakan bahwa tingkat pendidikan ibu rumah tangga mempengaruhi tingkat ketahanan pangan.
Variabel pengeluaran pangan rumah tangga berpengaruh negatif terhadap tingkat ketahanan pangan rumah tangga nelayan dengan tingkat kepercayaan sebesar 99,03 persen. Besarnya pengeluaran pangan rumah tangga mencerminkan pendapatan rumah tangga yang dibelanjakan untuk memenuhi kebutuhan pangan. Hasil penelitian ini sejalan dengan hasil penelitian Hernanda, Indriani, dan Listiana (2013) yang menyatakan bahwa pengeluaran pangan berpengaruh terhadap tingkat ketahanan pangan.

\section{Upaya untuk meningkatkan ketahanan pangan}

Upaya yang dilakukan oleh pemerintah di lokasi penelitian terdiri dari kegiatan pemantauan ketersediaan pangan dan cadangan pangan serta pengembangan distribusi dan stabilitas harga pangan, pengembangan penganekaragaman konsumsi dan keamanan pangan, Program Keluarga Harapan (PKH) dan bantuan pangan pokok melalui program Raskin. Upaya yang dilakukan oleh rumah tangga nelayan yaitu meminjam bahan pangan $(92,16 \%)$ meliputi bahan pangan pokok, sayuran, lauk-pauk, minyak goreng, dan gula serta mengubah pola makannya $(7,84 \%)$ dengan menurunkan kualitas pangan yang dikonsumsi atau mengurangi porsi makanan yang dikonsumsi oleh rumah tangga tersebut.

\section{KESIMPULAN}

Berdasarkan hasil penelitian, dapat disimpulkan bahwa sebagian besar rumah tangga nelayan di Desa Sukajaya Lempasing tergolong dalam kategori kurang pangan $(68,63 \%)$, sedangkan kategori tahan, rentan, dan rawan pangan masingmasing $(13,75 \%, 3,88 \%, 11,76 \%)$. Faktor yang mempengaruhi tingkat ketahanan pangan rumah tangga nelayan adalah tingkat pendidikan ibu rumah tangga dan pengeluaran pangan rumah tangga. Upaya yang dilakukan oleh pemerintah di lokasi penelitian terdiri dari kegiatan pemantauan ketersediaan pangan dan cadangan pangan serta pengembangan distribusi dan stabilitas harga pangan, pengembangan penganekaragaman konsumsi dan keamanan pangan, Program Keluarga Harapan (PKH) dan bantuan pangan pokok melalui program Raskin, Upaya yang dilakukan oleh rumah tangga nelayan yaitu meminjam bahan pangan $(92,16 \%)$ meliputi bahan pangan pokok, sayuran, lauk-pauk, minyak goreng, dan gula, serta mengubah pola makannya $(7,84 \%)$ dengan menurunkan kualitas pangan yang dikonsumsi atau mengurangi porsi makanan yang dikonsumsi oleh rumah tangga. 


\section{DAFTAR PUSTAKA}

Arikunto S. 1996. Prosedur Penelitian: Suatu Pendekatan Praktek. PT. Rineka Cipta. Jakarta.

Adriani, M dan Wirjatmadi, B. 2012. Pengantar Gizi Masyarakat. https://books.google.co.id/ books?id=kqhADwAAQBAJ \& printsec=frontc over\# $\mathrm{v}=$ onepage $\& \mathrm{q} \& \mathrm{f}=$ false $\quad[3$ Desember 2018].

Anggraini M, Zakaria WA, dan Pramatiwi FE. 2014. Ketahanan pangan rumah tangga petani kopi di Kabupaten Lampung Barat. JIIA, 2 (2):130 http://jurnal.fp.unila.ac.id/index.php/JI A/article/download/1641/1467. [30 September 2018].

BKP [Badan Ketahanan Pangan]. 2016. Buletin Harga Pangan. BKP Kementerian Pertanian.

BPS [Badan Pusat Statistik] Provinsi Lampung. 2016. Jumlah Rumah Tangga Perikanan Tangkap Berdasarkan Kecamatan di Provinsi Lampung. Penerbit BPS Provinsi Lampung. Lampung.

BPS [Badan Pusat Statistik] Provinsi Lampung. 2018. Indikator Kesejahteraan Rakyat Provinsi Lampung. Penerbit BPS Provinsi Lampung. Lampung.

Dewan Ketahanan Pangan, 2015. Kebijakan Strategis Pangan dan Gizi Tahun 2015 2019. http://bkp.pertanian.go.id/storage/app /media/informasi\%20publik/Pedoman/KSPG 2015-2019(2).pdf. [3 Desember 2018].

Dinas Kelautan dan Perikanan Kabupaten Pesawaran. 2016. Produksi Perikanan Tangkap Menurut Kecamatan dan Subsektor di Kabupaten Pesawaran 2014-2015 (dalam ton). Penerbit Dinas Kelautan dan Perikanan Kabupaten Pesawaran. Lampung.

Dinas Ketahanan Pangan Kabupaten Pesawaran. 2017. Analisis Pola Pangan Harapan (PPH) Tahun 2017. Dinas Ketahanan Pangan Kabupaten Pesawaran. Lampung.

Hardinsyah D dan Martianto. 1989. Cara Menghitung Angka Kecukupan Energi dan Protein Serta Penilaian Mutu Gizi Konsumsi Pangan. Wirasari. Jakarta.

Hernanda T, Indriani Y, dan Listiana I. 2013. Pendapatan usaha tani jagung dan ketahanan pangan rumah tangga petani di Kecamatan Simpang Kabupaten Ogan Komering Ulu Selatan. JIIA, 1(4):311-318. http://jurnal.fp. unila.ac.id/index.php/JIA/article/view/1641/1 467 [3 Desember 2017].
Mantra I. 2004. Filsafat Penelitian dan Metode Penelitian Sosial. Pustaka Belajar Offset. Yogyakarta.

Maxwell D et.al. 2000. Urban Livelihoods and Food Nutrition Security in Greater Accra, Ghana. IFPRI in Collaborative with Noguchi Memorial for Medical Researce and World Health Organization, Researce Report No.112.Washington,D.C. http://www.nzdl.org /gsdlmod?e=d-00000-00---off-0fnl2.2--00-0---0-10-0---0---0direct-10---4-------0-11--11-en50---20-about---00-0-1-00---4----0-0-11-10ut fZz-8-00\&cl=CL2.8\&d=HASHde8517bd7f52 $1582 f 7 \mathrm{a} 1 \mathrm{e} 0.17 \& \mathrm{x}=1$ [18 November 2017].

Nurdiani U dan Widjojoko T. 2016. Faktor-faktor yang mempengaruhi ketahanan pangan rumah tangga miskin di wilayah perkotaan Kabupaten Banyumas. Jurnal Penelitian Pertanian. Agrin, 20 (2): 177. http://jurnal agrin.net/index.php/agrin/article/view/324 [25 Mei 2018].

Pemerintah Daerah Provinsi Lampung. 1999. Atlas Sumberdaya Wilayah Pesisir Lampung. Pemerintah Provinsi Lampung. Lampung.

Perdana dan Hardinsyah. 2013. Analisis jenis, jumlah dan mutu gizi konsumsi sarapan anak Indonesia. Jurnal Gizi dan Pangan, 8(2):3946. http://journal.ipb.ac.id/index.php/jgizipa ngan/article/download/7251/5663.

Desember 2017].

Purwaningsih Y. 2008. Ketahanan pangan: situasi, permasalahan, kebijakan, dan pemberdayaan masyarakat. Jurnal Ekonomi Pembangunan, 9 (1):17-18. http://mesp.fe.uns.ac.id/media/ Ketahanan\%20Pangan\%202008.pdf. [26 Mei 2018].

Salim FD dan Darmawaty 2016. Kajian ketahanan pangan rumah tangga nelayan buruh di Desa Bajo Sangkuang Kabupaten Halmahera Selatan. Jurnal Sosek KP, 11 (1) 121-132. http://ejournalbalitbang.kkp.go.id/index.php/s osek/article/download/3177/2685. November 2017].

LIPI [Lembaga Ilmu Pengetahuan Indonesia]. 2012. Widyakarya Nasional Pangan dan Gizi (WNPG) X tahun 2012. Prosiding. LIPI. Jakarta.

Yuliana P, Zakaria WA, dan Adawiyah R. 2013. Ketahanan pangan rumah tangga nelayan di Kecamatan Teluk Betung Selatan Kota Bandar Lampung. JIIA, 1 (2) 181-186. http://jurnal.fp.unila.ac.id/index.php/JIA/artic le/view/246/245. [18 November 2017]. 